\section{STATISTICAL OPTIMIZATION AND CHARACTERIZATION OF ACOUSTICALLY EXTRACTED ANANAS COMOSUS PEEL POWDER WITH ENHANCED ANTIOXIDANT CAPACITY}

Article history

Received

10 December 2019

Received in revised form

24 April 2020

Accepted

30 April 2020

Published online

22 June 2020

Nur Azzanizawaty Yahya,b,c, Roswanira Abdul Wahaba,b*, Mariani Abdul Hamidc, Naji Arafat Mahata,b,d,e, Mohamad Afiq Mohamed Huria, Nursyafreena Attana, Siti Ernieyanti Hashima
*Corresponding author roswanira@kimia.fs.utm.my

aDepartment of Chemistry, Faculty of Science, Universiti Teknologi Malaysia, 81310 UTM Johor Bahru, Johor, Malaysia bEnzyme Technology and Green Synthesis Group, Faculty of Science, Universiti Teknologi Malaysia, 81310 UTM Johor Bahru, Johor, Malaysia

cSchool of Chemical and Energy Engineering, Faculty of Engineering, Universiti Teknologi Malaysia, 81310 UTM Johor Bahru, Johor, Malaysia

aCentre for Sustainable Nanomaterials, Ibnu Sina Institute for Scientific and Industrial Research, Universiti Teknologi Malaysia, 81310 UTM Johor Bahru, Johor, Malaysia

eCentre of Research for Fiqh Forensics and Judiciary, Universiti Sains Islam Malaysia, Bandar Baru Nilai, 71800, Nilai, Negeri Sembilan, Malaysia

\footnotetext{
Graphical abstract

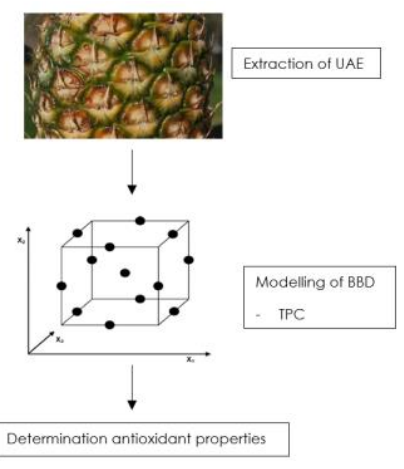

\begin{abstract}
Ananas comosus (L.) Merr is one of many commercially popular fruits in the cannery food industry that contributes to the increasingly mounting agro-industrial waste. In this study, a four-factor-three-level Box-Behnken design (BBD) that comprised of sonication time (A), solvent ratio (B), amplitude (C) and liquid-solid ratio (D) for the ultrasound-assisted extraction (UAE) of pineapple peels (PP) was utilized to optimize the yield of total phenolic content (TPC). Under an optimized UAE condition [5 min; $50 \%$ of ethanol: water; $65 \%$ of amplitude; $35: 1 \mathrm{~mL} / \mathrm{g}$ of liquid-solid ratio], the highest TPC from PP of $708.10 \mathrm{mg}$ gallic acid equivalent (GAE)/g DW was achieved. Antioxidant capacity analysis of PP revealed a high total flavonoid content (TFC) with the $I_{50}$ for 2,2-diphenyl-1-picrylhydrazyl (DPPH), and ferric reducing antioxidant power (FRAP) of $1146.86 \pm 11.83 \mathrm{mg} \mathrm{QE} / \mathrm{g}, 11.83 \mathrm{mg} / \mathrm{mL}$ and $1578.07 \pm 25.96 \mu \mathrm{M}$ Fe (II)/100g, respectively. High-performance liquid chromatography (HPLC) analysis revealed that the major flavonoid in the phenolic profile of PP extracts being catechin followed by quercetin and gallic acid. The UAE of PP extracts exhibited higher TPC than known conventional extraction techniques, thus indicating its efficacy to recover satisfactory quantities of phenolics in PP under optimized conditions.
\end{abstract}

Keywords: Ananas comosus peels, ultrasound-assisted extraction, response surface methodology, Box-Behnken design, antioxidant capacities
} 


\begin{abstract}
Abstrak
Ananas comosus (L.) Merr adalah salah satu daripada buah komersial yang terkenal di dalam industri pengetinan makanan yang menyumbang kepada peningkatan sisa agroindustri. Dalam kajian ini, suatu reka bentuk kotak-Behnken (BBD) empat faktor-tiga tahap yang terdiri daripada masa sonikasi (A), nisbah pelarut (B), amplitud (C) dan nisbah cecairpepejal (D) untuk pengekstrakan kulit nenas (PP) berbantukan ultrabunyi (UAE) telah digunakan untuk mengoptimumkan jumlah hasil kandungan fenolik (TPC). Di bawah keadaan UAE teroptimumkan [5 min, 50 \% etanol: air; $65 \%$ amplitud; $35: 1 \mathrm{~mL} / \mathrm{g}$ nisbah cecair-pepejal], TPC tertinggi dari PP sebanyak $708.10 \mathrm{mg}$ asid galik setara (GAE)/g DW telah dicapai. Analisis kapasiti antioksidan PP menunjukkan jumlah kandungan flavonoid (TFC) tertinggi dengan IC 50 untuk 2,2-difenil-1-pikrilhidrazil (DPPH), dan kuasa antioksidan mengurangkan ferik (FRAP) masing-masing ialah $1146.86 \pm 11.83 \mathrm{mg} \mathrm{QE} / \mathrm{g}, 11.83 \mathrm{mg} / \mathrm{mL}$ and $1578.07 \pm 25.96 \mu \mathrm{M} \mathrm{Fe}(\mathrm{II}) / 100 \mathrm{~g}$. Analisis kromatografi cecair berprestasi tinggi (HPLC) menunjukkan flavonoid utama dalam profil ekstrak fenolik PP ialah katekin diikuti oleh kuercetin dan asid galik. Ekstrak PP UAE menunjukkan TPC yang agak tinggi berbanding pengekstrakan konvensional yang diketahui, maka menunjukkan keberkesanannya bagi mendapatkan kuantiti fenolik dalam PP yang memuaskan di bawah keadaan optimum.

Kata kunci: Kulit Ananas comosus, pengekstrakan dibantu ultrabunyi, metodologi permukaan tindak balas, reka bentuk kotak-Behnken, kapasiti antioksidan

(C) 2020 Penerbit UTM Press. All rights reserved
\end{abstract}

\subsection{INTRODUCTION}

Ananas comosus (L.) Merr, otherwise known 'nanas' in Southeast Asia or pineapple in English, is a plant from the Bromeliaceae family that is native to the Central and South Americas [1] and grows well in tropical and subtropical regions, such as Thailand, Malaysia, Philippines, India, China, Hawaii, South Africa and Kenya. Its yellow, sweet-flavored flesh contains an appreciably high content of carotenoid, which causes the pulp to have the same hue as the peels. $[2,3]$. Being the $18^{\text {th }}$ world's largest pineapple producer with over 330,000 metric tons of pineapple harvested a year, the monitoring and regulating processes of all agro-industrial activities related to pineapple and its related products in Malaysia are performed by Malaysian Pineapple Industry Board (MPIB) [4].

In tandem with the high demands for pineapple products, the accumulation of unwanted pineapple peels (PP) and sugar-rich industrial effluents can be an immediate environmental problem. Pineapple industries produce enormous quantities of waste, inter alia crown and leaves are removed before the juice is extracted, constituting $50 \%(\mathrm{w} / \mathrm{w})$ of the biomass [5]. The high biomass turnover from the manufacturing processes has contributed to the high volume of wastes, and hence, rendered serious environmental challenges such as the need for larger landfills that may eventually lead to serious greenhouse effects.

Therefore, concerted efforts by the manufacturers and scientific community are crucial to alleviate this issue, wherein the polyphenolic-rich PP can be recovered and extracted for other potential uses. It has been indicated that PP is a reservoir for bioactive compounds like phenolics and antioxidants [6]. These compounds are known for their beneficial properties on human health such as anti-inflammatory and anti-allergenic, as well as cardio and neuroprotective effects. Likewise, the polyphenolic-rich PP extracts are useful as value-added products in certain manufacturing industries, such as pharmaceutical and cosmeceutical industries [ $[1,6]$. Hence, exploring the chemical wealth of this biomass while establishing various avenues to efficiently recover these compounds from PP biomass merits scientific consideration.

Conventionally, hot/cold maceration, solvent extraction, and hydro-distillation are employed for recovering plant phenolics in its powdery form [7], but the techniques have low efficiency and yield, as well as higher consumption of energy, time and solvents. Therefore, relatively more efficient and greener techniques need to be developed, and in this context, the more modern ultrasound-assisted extraction (UAE) technique may provide better pharmacological and technological advantages [8]. The higher efficiency of UAE can be attributed to the acoustic and mechanical effects that perpetuate the formation and breakdown of bubbles in the liquid extraction medium. Cavitation bubbles that formed dynamically and imploded in the surrounding liquid would bombard and disintegrate the plant cell wall, liberating phenolic compounds. It is worth to indicate here that, such effects of UAE can only occur in liquids and liquid-containing solid materials [9]. The favorable effects of UAE to extract phenolics compounds have been demonstrated on a myriad of plant materials $[10,11]$.

Although various experimental designs for optimizing extraction procedures have been reported [12], response surface methodology (RSM) 
remains the most commonly employed method for optimization [8]. RSM enables the evaluation of the interactive factors in the process [13] and reduce optimization experiments and therefore, less time-consuming $[12,14]$.

While the chemistry and bioactive compounds extraction from different parts of pineapple viz. leaves [15], pulp and fruit [16] using conventional techniques have been described, the state-of-art UAE extraction technique for PP remains unreported. Herein, this study used the Box-Behnken design (BBD) to establish the best condition for UAE of the PP extract. The study specifically optimized the sonication time (A), solvent ratio (B), amplitude (C) and liquid-solid ratio (D) for the response of the highest TPC and characterized the antioxidant activity of the ultrasonically obtained PP extract.

\subsection{METHODOLOGY}

\subsection{Plant Materials}

The freshly harvested Ananas comosus L. Merr peels were obtained from a local fruit stall at Taman Universiti, Johor Bahru. The peels were thoroughly rinsed under running tap water to remove surface impurities and dried in a ventilated oven for 2 days at $50^{\circ} \mathrm{C}$. The desiccated peels were pulverized using a laboratory grinder followed by sifting through a 40-mesh sieve to obtain uniformly size powder. The PP powder was transferred into ziplocked bags and kept at $4^{\circ} \mathrm{C}$.

\subsection{Response Surface Methodology (RSM) for the UAE of PP}

A BBD using the Design Expert 7.1.6 (DX7, Stat-Ease, Inc.) that comprised of four variables and a total of 29 reactions was used to monitor the response pattern and establish the optimal conditions for obtaining TPC. The independent factors selected for the optimization of UAE were as follows: A (sonication time, min), B (solvent ratio, \%), C (amplitude, \%) and D (liquid-solid ratio, $\mathrm{mL} / \mathrm{g}$ ). The independent variables and actual values, as well as coded values in the experimental design are illustrated in Table 1.

Table 1 Independent variables and their levels using BBD for the UAE of PP

\begin{tabular}{lcccc}
\hline \multirow{2}{*}{ Variables } & \multirow{2}{*}{ Symbols } & \multicolumn{3}{c}{ Levels } \\
\cline { 3 - 5 } & & $\mathbf{- 1}$ & $\mathbf{0}$ & $\mathbf{+ 1}$ \\
\hline Sonication time (min) & $\mathrm{A}$ & 5 & 30 & 55 \\
Solvent ratio (\%) & $\mathrm{B}$ & 20 & 50 & 80 \\
Amplitude (\%) & $\mathrm{C}$ & 30 & 65 & 100 \\
Liquid-solid ratio (mL/g) & $\mathrm{D}$ & 15 & 25 & 35 \\
\hline
\end{tabular}

The model equation was used to estimate the best experimental conditions, and to describe the interaction between the assessed parameters (Eqn. 1):

$$
Y=\beta_{0}+\sum_{j=1}^{k} \beta_{j} X_{j}+\sum_{j=1}^{k} \beta_{j j} X_{j}^{2}+\sum_{\mathrm{j}=1}^{1-1} \sum_{\mathrm{k}=2}^{l} \beta_{j k} X_{j} X_{k}+\varepsilon
$$

where $Y$ is the response; $j$ and $k$ are the linear and quadratic coefficients, respectively, $X_{i}$ and $X_{j}$ are the uncoded independent parameters, I represents the number of studied and optimized variables in the experiment, $\beta_{0}$ is a constant coefficient; $\beta_{\mathrm{j}}, \beta_{\mathrm{jj}}$ and $\beta_{\mathrm{jk}}$ are the interaction coefficients of linear, quadratic and second-order terms, respectively; and finally, $\varepsilon$ is the error.

Analysis of variance (ANOVA) with $95 \%$ confidence level was performed in this study to assess both the effect of each factor and the predicted model on the response. Model fitness was evaluated using the regression coefficient $\left(R^{2}\right)$, $p$-value, coefficient of variation (CV) and $p$-value of the lack of fit (LOF). The optimal extraction condition was the response, chosen based on the highest value of TPC.

\subsection{Ultrasound-assisted Extraction (UAE) of} Pineapple Peels (PP)

A $20 \mathrm{kHz}$ ultrasonic generator (130 W, KH5200DB type, Kunshan ultrasonic instrument Co., Ltd., Jiangsu, China) was used in the extraction of PP powder. For each extraction, PP powder (1 g) was transferred into a $50 \mathrm{~mL}$ beaker that contained a mixture of ethanol: water. Each mixture was homogenized for $40 \mathrm{~s}$ before the ultrasonication was carried out to extract the phenolic compounds. UAE of PP was investigated for the effects of i) sonication time (5 - $55 \mathrm{~min})$, ii) solvent ratio (20-80\%), iii) amplitude (30-100\%) and iv) liquid-solid ratio $(15-35 \mathrm{~mL} / \mathrm{g})$, as specified by the BBD matrix (Table 1). During extraction, temperature of each extraction mixture was held at $30^{\circ} \mathrm{C} \pm 1^{\circ} \mathrm{C}$ by immersing the beaker in an ice-bath and a thermometer was used for monitoring the temperature.

\subsection{Determination of Total Phenolic Content (TPC)}

In this study, the test was performed on all samples run in the BBD experiment. PP extract in ethanol: water $(0.30 \mathrm{~mL}, 1 \mathrm{mg} / \mathrm{mL})$ was mixed thoroughly with Folin-Ciocalteau reagent $(0.30 \mathrm{~mL})$ and distilled water $(2.70 \mathrm{~mL})$. After $5 \mathrm{~min}$ of incubation at room temperature $\left(25^{\circ} \mathrm{C}\right), 7 \%$ of $\mathrm{Na}_{2} \mathrm{CO}_{3}$ solution $(3.00 \mathrm{~mL})$ and distilled water $(1.20 \mathrm{~mL})$ were added to the mixture, mixed and allowed to stand for $30 \mathrm{~min}$ at room temperature. The absorbance was read at 765 $\mathrm{nm}$ using Lambda 25 UV/VIS Spectrometer (Perkin Elmer, United States). A standard curve was prepared using gallic acid (0 - $10 \mathrm{mg} / \mathrm{mL})$ against different solvent ratios of ethanol: water as the blank. The readings were triplicated, and the results were 
expressed as milligrams of gallic acid equivalent per gram (mg GAE/g) of dry sample.

\subsection{Determination of Antioxidant Activities of PP}

The antioxidant activity of the PP extracts was examined using three different techniques viz. total flavonoid content (TFC), 2,2-diphenyl-1-picrylhydrazyl (DPPH) assay and ferric reducing antioxidant power (FRAP) via T60 Visible Spectrophotometer (PG Instruments Limited, United Kingdom).

\subsubsection{Total Flavonoid Content (TFC)}

Briefly, a sample $(1 \mathrm{mg} / \mathrm{mL}$ ) was mixed with $0.9 \mathrm{~mL}$ of $5 \%$ sodium nitrite, $\mathrm{NaNO}_{2}(\mathrm{w} / \mathrm{v})$. After $5 \mathrm{~min}$ of incubation at $25^{\circ} \mathrm{C}, 1.5 \mathrm{~mL}$ of $2 \%$ aluminum chloride, $\mathrm{AlCl}_{3}(\mathrm{w} / \mathrm{v})$ was added and the mixture was left at room temperature for $6 \mathrm{~min}$. After that, the solution was neutralized with $1.5 \mathrm{~mL}$ of $1 \mathrm{M}$ of $\mathrm{NaOH}$ solution. The TFC was estimated using the calibration curve obtained from serial dilutions of varying concentrations of quercetin $(0-10 \mathrm{mg} / \mathrm{mL})$ diluted in ethanol: water $(50: 50, v / v)$ and read at $510 \mathrm{~nm}$ after 10 min of incubation at room temperature. The same solvent mixture of ethanol: water $(50: 50 \%, v / v)$ was used as the blank. All readings were triplicated and the results expressed as milligrams of quercetin equivalent per gram (mg QE/g) of dry sample \pm standard deviation [17].

\subsubsection{DPPH Radical Scavenging}

PP extract was dissolved in ethanol: water $150: 50 \%$, $\mathrm{v} / \mathrm{v}$ ) with concentrations of samples ranging from 1.0 $-20.0 \mathrm{mg} / \mathrm{mL}$. For the test, sample PP extract $(0.1 \mathrm{~mL})$ was mixed with $2.4 \mathrm{~mL}$ of DPPH solution $(0.02 \mathrm{mg} / \mathrm{mL})$ in methanol, while the blank sample was prepared from $0.1 \mathrm{~mL}$ of PP extract mixed with $2.4 \mathrm{~mL}$ of methanol alone. The solutions were shaken vigorously and incubated in darkness at room temperature for $30 \mathrm{~min}$ before recording (in triplicates) the absorbance at $518 \mathrm{~nm}$. The radical scavenging activity (RSA) was calculated as the percentage of DPPH discoloration using Eqn. 2:

$$
\begin{aligned}
& \text { Radical scavenging activity, RSA }(\%)= \\
& {\left[\left(\text { ADPPH }-A_{s}\right) / A_{D P P H} \times 100\right.}
\end{aligned}
$$

where ADPPH and As being the absorbance of DPPH solution and test sample, respectively. The $\mathrm{IC}_{50}$ values of PP extract (concentration required to scavenge 50 $\%$ of the DPPH radicals) were estimated using the non-linear regression of plots derived from the plotted data using GraphPad Prism software version 5.02 (GraphPad Software, Inc., San Diego, USA).

\subsubsection{Ferric Reducing Antioxidant Power (FRAP)}

Briefly, $200 \mu \mathrm{L}$ of PP extract $(1.0 \mathrm{mg} / \mathrm{ml})$ was mixed with $1.8 \mathrm{~mL}$ of FRAP reagent $(300 \mathrm{mM}$ acetate buffer, $10 \mathrm{mM}$ TPTZ in $40 \mathrm{Mm}$ dilute $\mathrm{HCl}$ and $20 \mathrm{mM}$ Ferric chloride). After incubation at $37^{\circ} \mathrm{C}$ for 10 mins, the triplicate absorbance readings at $594 \mathrm{~nm}$ were recorded. PP extract containing solvent mixture of ethanol: water $(50: 50 \%, v / v)$ was used as the blank. The reducing ability of PP extract was expressed as micromolar of $\mathrm{Fe}^{2+}$ equivalent to 100 grams $(\mu \mathrm{M}$ of $\mathrm{Fe}^{2+} / 100 \mathrm{~g}$ ) of dry sample \pm standard deviation.

\subsubsection{HPLC Analysis}

The PP extracts were analyzed for quercetin, catechin and gallic acid using an Agilent Technologies 1260 Infinity Series HPLC equipped with a DAD detector and OpenLab Software (all technologies from Agilent Technologies, United States). PP crude extract ( $1 \mathrm{mg} / \mathrm{mL})$ was dissolved in HPLC grade methanol $(50 \%, v / v)$ before filtering through a $0.45 \mu \mathrm{m}$ nylon microfilter (Membrane Solutions).

The filtered PP crude extract $(20 \mu \mathrm{L})$ was injected into the Supelco Ascentis C-18 column $(5 \mu \mathrm{m}, 25 \mathrm{~cm} x$ $4.60 \mathrm{~mm}$, Sigma Aldrich, Malaysia), and the analysis conditions for the polyphenols detailed below. System 1: The mobile phase consisted of $0.1 \%(\mathrm{v} / \mathrm{v})$ acetic acid in water (Elvent A) and mobile $100 \%$ acetonitrile (Elvent $B$ ) using a gradient program as follows: $90 \%$ A: $10 \%$ B (0 - $5 \mathrm{~min}), 70 \%$ A: $30 \%$ B (5$13 \mathrm{~min}), 90 \%$ A: $10 \%$ B (13 - 15 min). System 2: The mobile phase consisted of $5 \%(\mathrm{v} / \mathrm{v})$ acetic acid in water (Elvent A) and mobile $100 \%$ methanol (Elvent B) using an isocratic program of A: B (30:70 \%). Detection wavelengths for both systems were performed at 280 and $360 \mathrm{~nm}$, respectively. Constant flow rate of $1.0 \mathrm{~mL} / \mathrm{min}$ was utilized for both systems.

HPLC systems 1 and 2 were employed to detect gallic acid, as well as catechin and quercetin, respectively. The PP extract was spiked with standards $(25 \mathrm{ppm})$ in methanol: water $(50: 50 \%, \mathrm{v} / \mathrm{v})$. Identification of the phenolic compounds in the PP crude extract was made by comparing the retention times and absorption spectra of the samples with those of standards (gallic acid, quercetin and catechin). For quantification of gallic acid, catechin and quercetin, the respective calibration curves for each standard $(0-50 \mathrm{ppm})$ were constructed.

\subsection{RESULTS AND DISCUSSION}

\section{1 $\quad$ Fitting the Model}

Multiple regression analysis (MRA) of the BBD was performed to explore the relationship between the response of TPC and experimental levels of independent variables in the UAE. The mathematical models for the response in this study were expressed 
using the following Eqn. 3 in the form of coded values:

$\mathrm{Y}_{\mathrm{TPC}}=526.80-27.13 \mathrm{~A}+49.52 \mathrm{~B}-2.41 \mathrm{C}+49.08 \mathrm{D}+$ $0.35 A B-31.83 A C-52.26 A D-30.97 B C-32.69 B D-[3]$

$33.73 C D-7.51 A^{2}-240.60 B^{2}-9.94 C^{2}+38.55 D^{2}$

ANOVA of the fitted quadratic polynomial models for response TPC is shown in Table 2. The model was found as highly significant with $p<0.0001$. The data showed that the models satisfactorily fitted the response variable $\left(R^{2} T P C=0.9536\right)$, signifying the excellent correlation between the response values and independent variables. Also, the low CV observed for the TPC model at $9.79 \%$ indicated the high precision and reliability of the model [18]. Moreover, the insignificant lack of fit of model $(p>$ 0.05) further supported the reliability of the model to describe the correlation between independent variables and response [18].

The linear, interaction and quadratic terms $A, A D$ and $D^{2}$ were found significant $(p<0.05)$ for the response, TPC. The linear terms $B$ and $D$ were significant $(p<0.01)$ while the quadratic term $B^{2}$ was highly significant $(p<0.001)$ on the TPC (Table 3$)$. Figure 1 (Section 3.2) illustrates the perturbation, three-dimensional (3D) and contour plots of the linear and interaction effects on the TPC of the ultrasonically obtained PP extracts.

Table 2 Analysis of variance (ANOVA) for PP extract TPC

\begin{tabular}{|c|c|c|c|c|c|c|}
\hline Source & Sum of Square & df & Mean Square & F-value & $\rho$-value & Remarks \\
\hline Model & $5.246 E+005$ & 14 & 37471.21 & 20.56 & $<0.0001$ & Significant \\
\hline A & 8834.61 & 1 & 8834.61 & 4.85 & 0.0450 & \\
\hline B & 29429.74 & 1 & 29429.74 & 16.15 & 0.013 & \\
\hline C & 69.50 & 1 & 69.50 & 0.038 & 0.8480 & \\
\hline$D$ & 28907.14 & 1 & 28907.14 & 15.86 & 0.0014 & \\
\hline$A B$ & 0.49 & 1 & 0.49 & $2.689 E-004$ & 0.9871 & \\
\hline$A C$ & 4053.23 & 1 & 4053.23 & 2.22 & 0.1581 & \\
\hline$A D$ & 10925.48 & 1 & 10925.48 & 5.99 & 0.0281 & \\
\hline$B C$ & 3835.94 & 1 & 3835.94 & 2.10 & 0.1689 & \\
\hline $\mathrm{BD}$ & 4275.85 & 1 & 4275.85 & 2.35 & 0.1479 & \\
\hline$C D$ & 4550.85 & 1 & 4550.85 & 2.50 & 0.1364 & \\
\hline$A^{2}$ & 366.19 & 1 & 366.19 & 0.20 & 0.6608 & \\
\hline $\mathrm{B}^{2}$ & $3.755 E+005$ & 1 & $3.755 E+005$ & 206.03 & $<0.0001$ & \\
\hline$C^{2}$ & 641.03 & 1 & 641.03 & 0.35 & 0.5626 & \\
\hline$D^{2}$ & 9638.42 & 1 & 9638.42 & 5.29 & 0.0374 & \\
\hline Lack of Fit & 22449.03 & 10 & 2244.90 & 2.93 & 0.1560 & Not significant \\
\hline$R^{2}$ & & & 0.9536 & & & \\
\hline$R^{2} a d j$ & & & 0.9072 & & & \\
\hline C.V. \% & & & 9.79 & & & \\
\hline
\end{tabular}


Table 3 Experimental design and results of the BBD for the UAE of PP for TPC (mg GAE/g DW)

\begin{tabular}{|c|c|c|c|c|c|}
\hline Run & $\begin{array}{c}A \\
(\min )\end{array}$ & $\begin{array}{l}\text { B } \\
(\%)\end{array}$ & $\begin{array}{c}C \\
(\%)\end{array}$ & $\begin{array}{c}D \\
(\mathrm{~mL} / \mathrm{g})\end{array}$ & $\begin{array}{c}\text { Total phenolic } \\
\text { content (mg } \\
\text { GAE/g DW) }\end{array}$ \\
\hline 1 & 30 & 20 & 65 & 15 & 181.37 \\
\hline 2 & 5 & 20 & 65 & 25 & 203.16 \\
\hline 3 & 30 & 50 & 100 & 35 & 548.46 \\
\hline 4 & 30 & 50 & 65 & 25 & 531.36 \\
\hline 5 & 55 & 50 & 100 & 25 & 434.44 \\
\hline 6 & 30 & 50 & 65 & 25 & 563.66 \\
\hline 7 & 5 & 50 & 30 & 25 & 497.15 \\
\hline 8 & 30 & 50 & 65 & 25 & 485.75 \\
\hline 9 & 55 & 50 & 65 & 35 & 487.65 \\
\hline 10 & 5 & 50 & 100 & 25 & 567.47 \\
\hline 11 & 5 & 80 & 65 & 25 & 324.48 \\
\hline 12 & 30 & 20 & 100 & 25 & 272.15 \\
\hline 13 & 30 & 20 & 65 & 35 & 390.16 \\
\hline 14 & 30 & 50 & 30 & 35 & 656.78 \\
\hline 15 & 30 & 80 & 65 & 15 & 301.29 \\
\hline 16 & 30 & 20 & 30 & 25 & 190.45 \\
\hline 17 & 30 & 80 & 65 & 35 & 379.30 \\
\hline 18 & 55 & 80 & 65 & 25 & 347.67 \\
\hline 19 & 30 & 80 & 100 & 25 & 330.80 \\
\hline 20 & 55 & 50 & 65 & 15 & 542.76 \\
\hline 21 & 5 & 50 & 65 & 15 & 554.16 \\
\hline 22 & 30 & 50 & 65 & 25 & 525.66 \\
\hline 23 & 55 & 50 & 30 & 25 & 491.45 \\
\hline 24 & 30 & 50 & 65 & 25 & 527.56 \\
\hline 25 & 55 & 20 & 65 & 25 & 224.95 \\
\hline 26 & 5 & 50 & 65 & 35 & 708.10 \\
\hline 27 & 30 & 80 & 30 & 25 & 372.97 \\
\hline 28 & 30 & 50 & 100 & 15 & 514.25 \\
\hline 29 & 30 & 50 & 30 & 15 & 487.65 \\
\hline
\end{tabular}

3.2 Effect of Extraction Parameters on Total Phenolic Content (TPC)

As shown in Table 3, the obtained TPC for the experiments ranged between 181.37 - $708.10 \mathrm{mg}$ $\mathrm{GAE} / \mathrm{g}$ DW, corresponding to minimum and maximum values for runs $\# 1$ and \#26, respectively. Pertinently, a higher TPC (708.10 mg GAE/g DW) was obtained here when compared to other reported conventional extraction techniques, reflux and maceration, that yielded only $7.98 \mathrm{mg} \mathrm{GAE} / \mathrm{g}$ DW [19] and $51.10 \pm 0.2 \mathrm{mg} \mathrm{GAE} / \mathrm{g} \mathrm{DW}$ [3], respectively. Moreover, TPCs that corresponded to $13.79 \pm 0.26 \mathrm{mg}$ GAE/ g DW and $1.41 \pm 0.06 \mathrm{mg}$ GAE/g DW were obtained for the dry and fresh residues of PP after the drying process, respectively [20]. Thus, the UAE described in this study provided better extraction of phenolic compounds from powdered PP than those reported in the body of literature $[3,19,20]$.

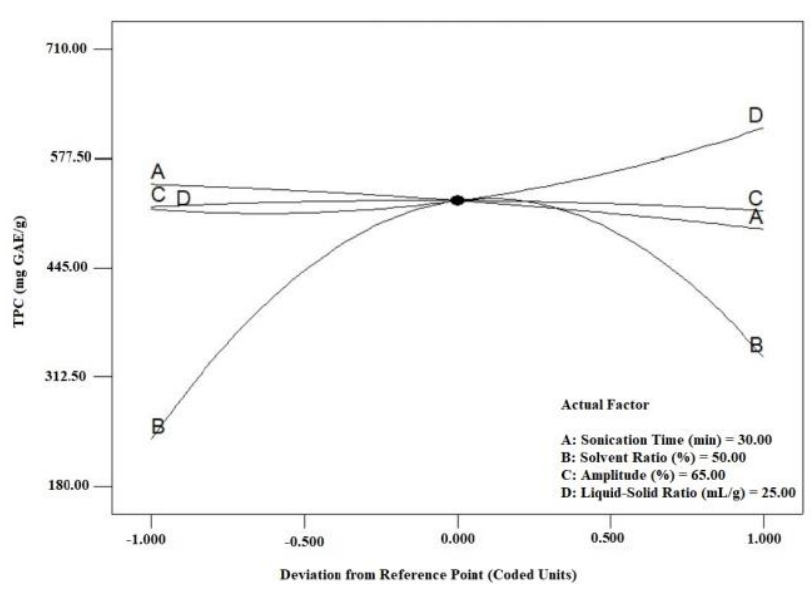

Figure 1 Pertubation plot showing the effect of four different parameters assessed on TPC (mg GAE/g)

It was also evident that the solvent ratio (B) and liquid-solid ratio (D) were the more significant factors that influenced the response (Figure 1), as seen from the extreme downward and slightly upward curve in the $3 \mathrm{D}$ plot, where the solvent ratio appeared to negatively affect TPC. TPC in the PP extracts increased concomitantly with increasing ethanol concentration up to the maximum of $50 \%$, beyond which the TPC started to decline due to issues related to similarity and inter-miscibility of the extracted components with the solvent mixture. Such findings appear consistent with those reported by previous researchers [21, 22]. In this study, the aqueous ethanol-water mixture was the solvent of choice due to low toxicity and its ability to better dissolve the phenolic compounds [22]. Both solvents acted in concert during UAE; water as the swelling agent while ethanol disrupts the solvent-solid contact of the plant cell wall [21]. The variable of liquid-solid ratio (D) showed a positive effect on TPC, whereby increased TPC was observed with the increase of the amount of liquid-solid ratio during UAE. This was presumably due to the higher contact area between the solvent and plant solute that boosted the diffusion of solvent molecules into the plant cell walls [12].

In our study, the mutual effect of $A D$ had significantly affected the TPC $(p<0.05)$, and the negative sign shown for Eqn. 3 further supported its relevance for improving the TPC. It implied that shorter sonication time (10-15 $\mathrm{min}$ ) with a high value of liquid-solid ratio $(33-35 \mathrm{~mL} / \mathrm{g})$ was needed for yielding such a high TPC (652.528 mg GAE/g) (Figure $2(i-i i))$. The interactive effect of $A D$ seen here was consistent with reports by previous researchers [11, 18], in which high yields of trans-lutein were obtained from pumpkin peel and total anthocyanin of Lycium ruthenicum Murr. fruit, respectively. 
(i)

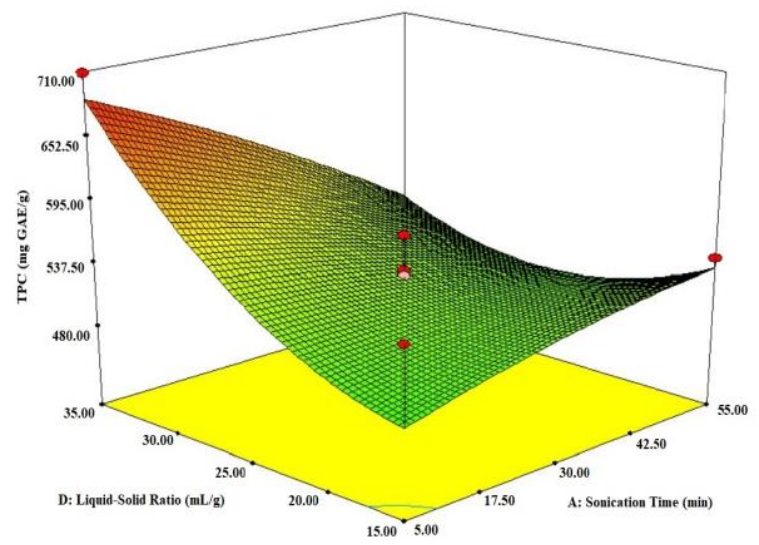

(ii)

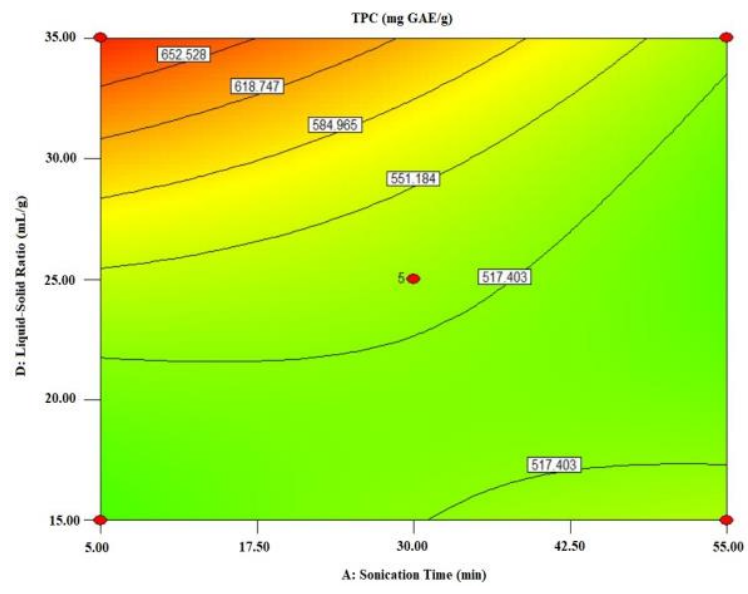

Figure 2 (i) Three-dimension (3D) response surface and (ii) contour plots showing the interactions between sonication time (A) and liquid-solid ratio (D) for response, TPC

It is known that prolonged sonication time tends to enhance extraction efficiency as more cell walls are ruptured, thus better diffusion of the solvent into the plant cell walls. However, over-sonication of the UAE mixture can adversely increase the surrounding liquid temperature and rapidly degrade the extracted bioactive compounds. Similar results were described by Chen et al. [11], Song et al. [18]. For that reason, a precautionary step was taken in this study by maintaining the extraction temperature at \pm $\sim 30{ }^{\circ} \mathrm{C}$ by immersing the vessel in an ice bath. This led to the high TPC of the PP extracts in this study at $708.10 \mathrm{mg} \mathrm{GAE} / \mathrm{g}$. Mild heating $\left(50^{\circ} \mathrm{C}\right.$ to $\left.70^{\circ} \mathrm{C}\right)$ have been shown as adequate to soften the plant tissues and release large quantities of bioactive compounds [23]. Hence, the upper limit or optimum temperature of the UAE on any plant materials must be known, as the UAE temperature may vary among plants due to variable thickness of the plant cell walls [24].

\subsection{Optimization of Extraction Parameters}

In this study, the economics of the UAE process was also duly considered while exploring the best condition for yielding the highest TPC, preferably conditions that utilized less time and solvent to achieve the desired output. Results revealed that 5 min sonication time, $50 \%$ solvent ratio, $65 \%$ amplitude and $35: 1 \mathrm{~mL} / \mathrm{g}$ liquid-solid ratio was optimum to extract the PP that yielded $708.10 \mathrm{mg} \mathrm{GAE} / \mathrm{g}$ (Table 2). This finding agreed well with the predicted 686.31 mg GAE/g of TPC showing the residual standard error (RSE) being less than 5\%. Hence, the best UAE condition for an appreciable yield of phenolic compounds from PP powder was identified.

\subsection{Determination of Antioxidant Activity}

Pyrzynska and Pekal [25] have suggested that at least two assays are required to reliably determine the antioxidant potential of an extract. In this regard, the present study employed three different assays to assess the antioxidant capacity of the obtained PP extracts. Total flavonoid content (TFC) was determined using the $\mathrm{AlCl}_{3}$ method, whereby the $\mathrm{AlCl}_{3}$ would form stable acid complexes with the C-4 keto groups, and either $\mathrm{C}-3$ or $\mathrm{C}-5$ hydroxyl group of flavones and flavanols [26], in addition to forming acid labile complexes with ortho-dihydroxyl groups in the A- or B-ring of flavonoids.

According to the calibration curve $(0-12 \mathrm{mg} / \mathrm{mL})$ for quercetin $\left(y=0.0488 x-0.0133, R^{2}=0.9649\right)$, the PP extract showed a TFC of $1146.86 \mathrm{mg} \mathrm{QE} / \mathrm{g}$, notably higher than TPC, and compared to reports by Morais et al. [27] (83.69 $\pm 14.83 \mathrm{mg} \mathrm{QE} / 100 \mathrm{~g})$ and da Silva et al. [28] $\left(76.93 \pm 11.85 \mu \mathrm{g}\right.$ of rutin $\left.100 \mathrm{~g}^{-1}\right)$ that used the $\mathrm{AlCl}_{3}$ and calorimetric method, respectively. The large difference observed here was presumably due to the different extraction methods used, as well as the provenance of the pineapple extract. Furthermore, conditions of the environmental surroundings were also expected to affect the constituents of the sample [3].

According to Pyrzynska and Pękal [25], DPPH assay is one of the well-documented methods for rapid assessment of antioxidant activity. The ability to donate hydrogen in this reaction is associated with the influence of antioxidants on scavenging DPPH radicals. In this present study, a trend of increasing radical scavenging ability was observed, reaching as high as $64.30 \%$ with increasing concentrations of the PP extract (Figure 3). Interestingly, the ethanol: water extracts of PP exhibited a higher percentage of inhibition (64.30\%) as compared to aqueous (61.48\%) and methanol (59.05\%) PP extracts alone, as previously reported by another study [29]. Since Alothman et al. [30] mentioned that the ethanolic pulp extract of pineapple showed the DPPH inhibition of $78.90 \pm 1.01 \%$, this present study then attempted to correlate the DPPH results with that of $\mathrm{IC}_{50}$. 


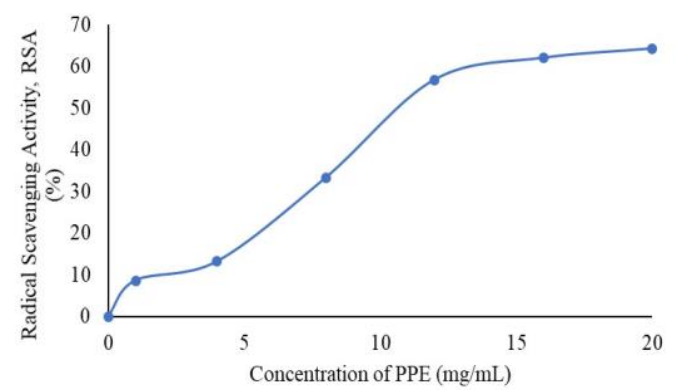

Figure 3 DPPH radical scavenging activity of PP extract

$\mathrm{IC}_{50}$ is defined as the inhibition concentration that reduces $50 \%$ of the DPPH radical concentration, whereby lower $\mathrm{IC}_{50}$ would indicate a stronger antioxidant activity [25]. The $\mathrm{IC}_{50}$ value for the PP extract (ethanol: water mixture) in this study was estimated as $11.83 \mathrm{mg} / \mathrm{mL}$ using the GraphPad Prism software. This was comparatively higher than the $1.745 \pm 0.046 \mathrm{mg} / \mathrm{mL}$ obtained by the UAE of pineapple peel and crown in methanol alone [31]. However, the use of methanol for obtaining plants extracts is undesirable due to toxicity, thereby necessitating the quest for a less toxic alternative, i.e. water-ethanol mixture [32].

FRAP assay is considered as one of the significant factors for determining antioxidants in plant samples [33], wherein the antioxidants would change the yellow $\mathrm{Fe}^{3+}$ solution to a blue $\mathrm{Fe}^{2+}$, as indicated by Kaneria and Chanda [34]. Correspondingly, the FRAP value of PP in this study was estimated to be 1578.07 $\pm 25.96 \mu \mathrm{M} \mathrm{Fe}{ }^{2+} / 100 \mathrm{~g} \mathrm{DW}$, based on the standard curve of aqueous $\mathrm{FeSO}_{4} .7 \mathrm{H}_{2} \mathrm{O}$ solution $\left(\mathrm{R}^{2}=0.9709\right)$. This was markedly higher than similar studies which used methanolic PP extracts of raw $(60.40 \pm 14.44 \mu \mathrm{M}$ $\mathrm{FeSO}_{4} / 100 \mathrm{~g}$ DW), oven dried (47.97 $\pm 8.04 \mu \mathrm{M}$ FeSO4/100 g DW) and lyophilized (25.99 $\pm 0.09 \mu \mathrm{M}$ $\mathrm{FeSO}_{4} / 100 \mathrm{~g} \mathrm{DW}$ ) peels [27]. Thus, the data supported the feasibility of probe-UAE technique for extracting phenolics from PP powder, showing satisfactory antioxidant capacity.

\subsection{HPLC Analysis}

The PP extracts were further analyzed using HPLC-DAD to quantify its phenolic compounds, and the results affirming their presence are presented in Table 4, as well as in Figures 4 and 5.
Table 4 Identification of phenolic composition of PP extract

\begin{tabular}{|c|c|c|c|c|}
\hline No. & Compounds & Type & $\begin{array}{c}\text { Retention } \\
\text { time }\left(R_{\mathrm{t}}\right)\end{array}$ & $\begin{array}{l}\text { Peak } \\
\text { Area }\end{array}$ \\
\hline \multirow{3}{*}{1.} & \multirow{3}{*}{ Gallic Acid } & Standard & 3.986 & 405.08 \\
\hline & & $\begin{array}{l}\text { Crude PP } \\
\text { extract }\end{array}$ & 4.002 & 29.47 \\
\hline & & $\begin{array}{l}\text { Spiked PP } \\
\text { extract }\end{array}$ & 4.033 & 403.46 \\
\hline \multirow{3}{*}{2.} & \multirow{3}{*}{ Catechin } & Standard & 8.755 & 999.24 \\
\hline & & $\begin{array}{l}\text { Crude PP } \\
\text { extract }\end{array}$ & 8.745 & 442.12 \\
\hline & & $\begin{array}{l}\text { Spiked PP } \\
\text { extract }\end{array}$ & 8.743 & 525.05 \\
\hline \multirow{3}{*}{3.} & \multirow{3}{*}{ Quercetin } & Standard & 3.480 & 2268.96 \\
\hline & & $\begin{array}{l}\text { Crude PP } \\
\text { extract }\end{array}$ & 3.478 & 149.40 \\
\hline & & $\begin{array}{l}\text { Spiked PP } \\
\text { extract }\end{array}$ & 3.474 & 725.91 \\
\hline
\end{tabular}

(a)

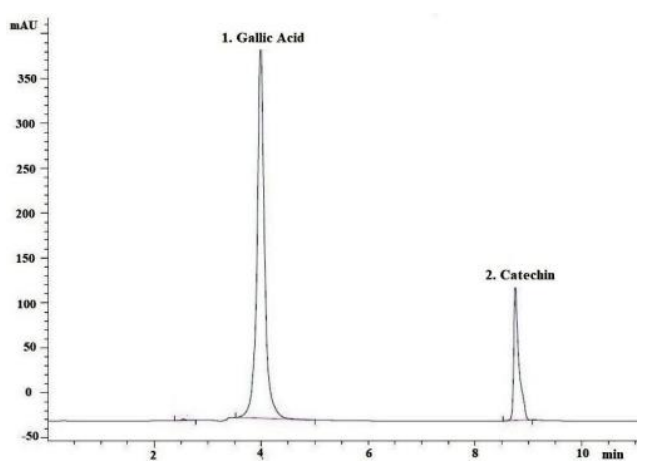

(b)

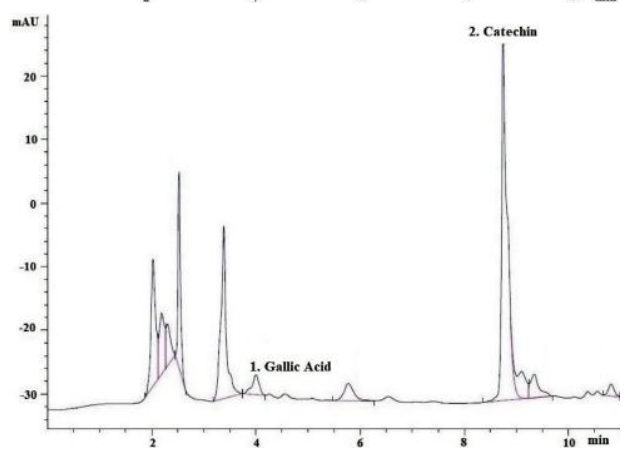

(c)

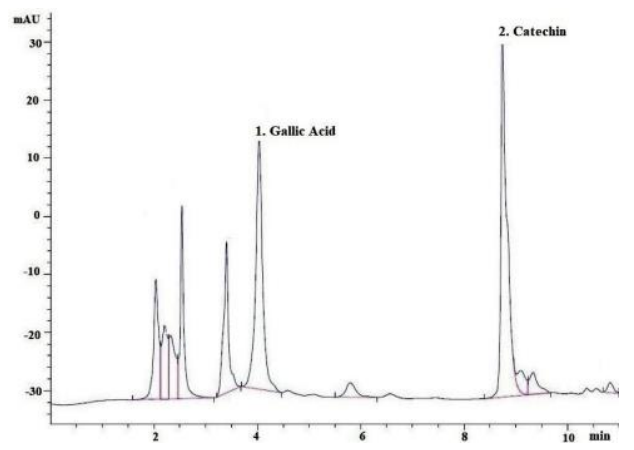

Figure 4 HPLC chromatogram of (a) standard gallic acid and catechin (b) crude PP extract and (c) spiked PP extract by System 1 
(a)

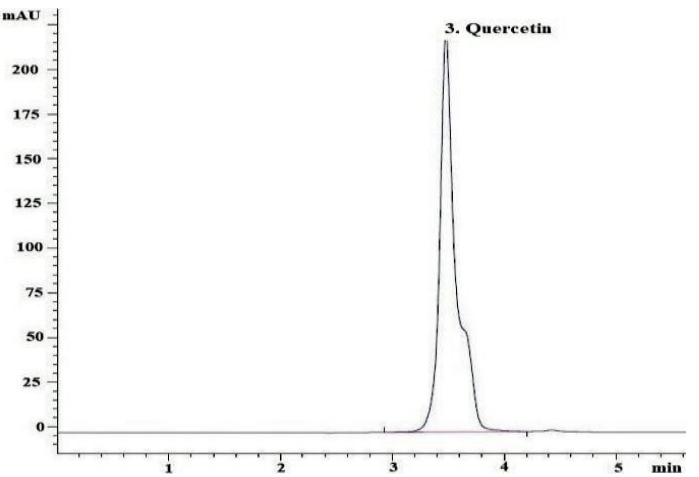

(b)

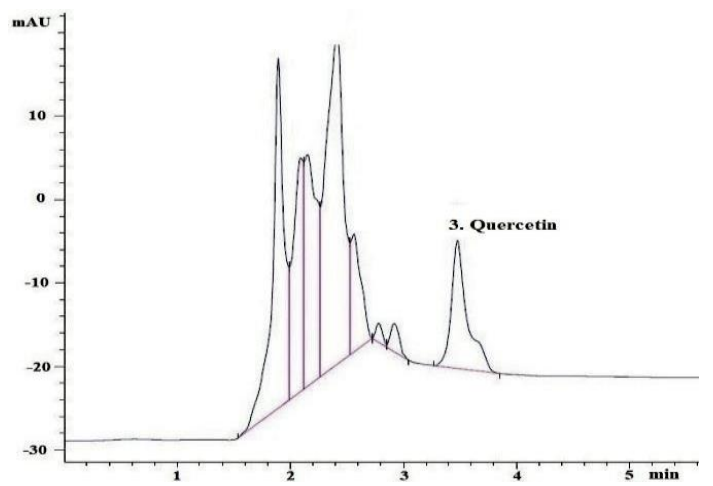

c)

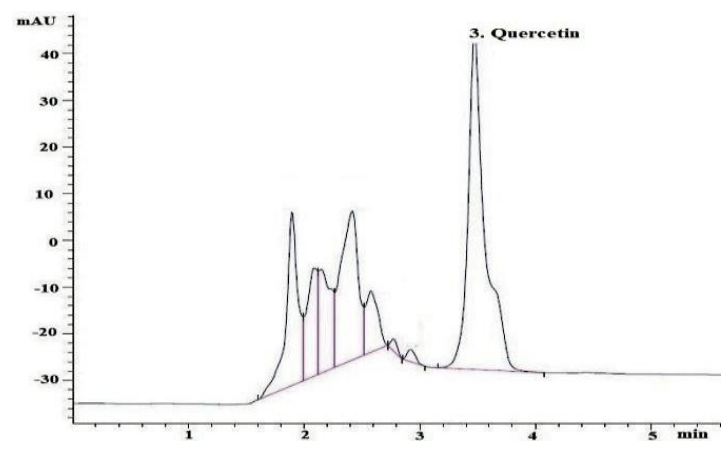

Figure 5 HPLC chromatogram (a) standard quercetin (b) crude PP extract and (c) spiked PP extract by System 2.

Gallic acid, catechin and quercetin in the samples eluted by $\sim 4.00, \sim 8.70$ and $\sim 3.40 \mathrm{~min}$ (Table 4), respectively, and they were consistent with that of the corresponding standards (Figures 4 and 5). The chromatogram also verified that that the ultrasonically obtained PP extract under optimized conditions contained $0.149 \%, 0.402 \%$ and $0.053 \%$ of quercetin, catechin and gallic acid, respectively. Pertinently, catechin was the major flavonoid followed by quercetin and gallic acid, in the PP extract. The fact that their corresponding regression coefficients $\left(R^{2}\right)$ were $0.9958,0.9965$ and 0.9979 for catechin, quercetin and gallic acid respectively, good linearity of HPLC analysis appears supported. The data reported here are also consistent with the data of TFC (Section 3.4). Similar with the findings reported by previous researchers [19], flavonoids were also the major polyphenolics in PP extract obtained by the reflux method.

\subsection{CONCLUSION}

The TPC in PP extract was successfully enhanced by $U A E$, demonstrating its ability as a competent and promising technique to extract polyphenolics compounds from ripen Ananas comosus peels. The optimum UAE conditions that gave the highest TPC (708.10 mg GAE/g DW) was established as follows: 5 min, $50 \%$ of solvent ratio, $65 \%$ of amplitude and 35:1 $\mathrm{mL} / \mathrm{g}$ of liquid-solid ratio. Factors such as sonication time, solvent ratio and liquid-solid ratio had significant effects on TPC for the UAE of PP extract. The high TFC (1146.86 mg QE/g) and moderate antioxidant capacity of the ultrasonically obtained $\mathrm{PP}$ extract $(11.83 \mathrm{mg} / \mathrm{mL}, 1578.07 \pm 25.96 \mu \mathrm{M} \mathrm{Fe}$ (II)/100 g) were also confirmed by $\mathrm{IC}_{50}$ for DPPH and FRAP assays. In a nutshell, it was shown that the modern state-of-art UAE technique can advantageously improve the extraction of chemical composition from PP extract, a greener option for further development of value-added products using the extracted polyphenolic compounds.

\section{Acknowledgement}

This work was supported by the Fundamental Research Grant Scheme from the Ministry of Higher Education Malaysia (R.J130000.7854.5F013).

\section{References}

[1] Kargutkar, S. and S. Brijesh. 2016. Anti-rheumatic Activity of Ananas Comosus Fruit Peel Extract in a Complete Freund's Adjuvant Rat Model. Pharmaceutical Biology. 54(11): 2616-2622. DOI: 10.3109/13880209.2016.1173066.

[2] Dhukani, A. 2013. Ananas Comosus (L.) Merr., Bromeliaceae. Medicinal Plant Monograph, C.L. Quave, Editor.

[3] Hossain, M. A. and S. M. M. Rahman. 2011. Total Phenolics, Flavonoids and Antioxidant Activity of Tropical Fruit Pineapple. Food Research International. 44(3): 672676. DOI: 10.1016/j.foodres.2010.11.036.

[4] Aditiya, H. B., W. T. Chong, T. M. I. Mahlia, A. H. Sebayang, M. A. Berawi, and H. Nur. 2016. Second Generation Bioethanol Potential from Selected Malaysia's Biodiversity Biomasses: A Review. Waste Management. 47: 46-61. DOI: https://doi.org/10.1016/j.wasman.2015.07.031.

[5] Khalid, N., H. Suleria, and I. Ahmed. 2016. Pineapple Juice. Handbook of Functional Beverages and Human Health, S. Fereidoon and A. Cesarettin, Editors. CRC Press: New York. 489-500.

[6] Barbulova, A., G. Colucci, and F. Apone. 2015. New Trends in Cosmetics: By-products of Plant Origin and Their Potential Use as Cosmetic Active Ingredients. Cosmetics. 2(2): 82-92. DOI: 10.3390/cosmetics2020082.

[7] Ameer, K., S. W. Bae, Y. Jo, H. G. Lee, A. Ameer, and J. H. Kwon. 2017. Optimization of Microwave-assisted Extraction of Total Extract, Stevioside and RebaudiosideA from Stevia Rebaudiana (Bertoni) Leaves, using Response Surface Methodology (RSM) and Artificial Neural Network (ANN) Modelling. Food Chemistry. 229: 198-207. DOI: 10.1016/j.foodchem.2017.01.121.

[8] Pilkington, J. L., C. Preston, and R. L. Gomes. 2014. Comparison of Response Surface Methodology (RSM) 
and Artificial Neural Networks (ANN) Towards Efficient Extraction of Artemisinin from Artemisia Annua. Industrial Crops and Products. 58: 15-24. DOI: 10.1016/j.indcrop.2014.03.016.

[9] Yahya, N. A., N. Attan, and R. A. Wahab. 2018. An Overview of Cosmeceutically Relevant Plant Extracts and Strategies for Extraction of Plant-based Bioactive Compounds. Food and Bioproducts Processing. 112: 6985. DOI: https://doi.org/10.1016/j.fbp.2018.09.002.

[10] Chan, C. H., T. Y. See, R. Yusoff, G. C. Ngoh, and K. W. Kow. 2017. Extraction of Bioactives from Orthosiphon Stamineus Using Microwave and Ultrasound-assisted Techniques: Process Optimization and Scale Up. Food Chemistry. 221: 1382-1387. DOI: 10.1016/j.foodchem.2016.11.016.

[11] Chen, S., Z. Zeng, N. Hu, B. Bai, H. Wang, and Y. Suo. 2018. Simultaneous Optimization of the Ultrasoundassisted Extraction for Phenolic Compounds Content and Antioxidant Activity of Lycium Ruthenicum Murr. Fruit Using Response Surface Methodology. Food Chemistry. 242: 1-8.

[12] Marzuki, N. H. C., M. A. Hamid, and R. A. Wahab. 2018. Assessment of Fatty Acid Composition and Response Surface Optimization of Ultrasonic-assisted Extraction of Phenolic Compounds from Pouteria Campechiana Pulp. Malaysian Journal of Fundamental and Applied Sciences. 14(2): 269-277.

[13] Hatambeygi, N., G. Abedi, and M. Talebi. 2011. Method Development and Validation for Optimised Separation of Salicylic, Acetyl Salicylic and Ascorbic Acid in Pharmaceutical Formulations by Hydrophilic Interaction Chromatography and Response Surface Methodology. Journal of Chromatography A. 1218(35): 5995-6003.

[14] Manan, F. M. A., N. Attan, Z. Zakaria, A. S. A. Keyon, and R. A. Wahab. 2018. Enzymatic Esterification of Eugenol and Benzoic Acid by a Novel Chitosan-Chitin Nanowhiskers Supported Rhizomucor Miehei Lipase: Process Optimization and Kinetic Assessments. Enzyme and Microbial Technology. 108: 42-52. DOI: https://doi.org/10.1016/j.enzmictec.2017.09.004.

[15] Emeka, E. E., O. C. Ojiefoh, C. Aleruchi, L. A. Hassan, O. M. Christiana, M. Rebecca, E. O. Dare, and A. E. Temitope. 2014. Evaluation of Antibacterial Activities of Silver Nanoparticles Green-synthesized Using Pineapple Leaf (Ananas Comosus). Micron. 57: 1-5. DOI: 10.1016/j.micron.2013.09.003.

[16] Difonzo, G., K. Vollmer, F. Caponio, A. Pasqualone, R. Carle, and C. B. Steingass. 2019. Characterisation and Classification of Pineapple (Ananas comosus [L.] Merr.) Juice from Pulp and Peel. Food Control. 96: 260-270. DOI: 10.1016/j.foodcont.2018.09.015.

[17] Drozdz, P., V. Seziene, and K. Pyrzynska. 2017. Phytochemical Properties and Antioxidant Activities of Extracts from Wild Blueberries and Lingonberries. Plant Foods for Human Nutrition. 72(4): 360-364. DOI: 10.1007/s $11130-017-0640-3$.

[18] Song, J., Q. Yang, W. Huang, Y. Xiao, D. Li, and C. Liu. 2018. Optimization of Trans Lutein from Pumpkin (Cucurbita moschata) Peel by Ultrasound-assisted Extraction. Food and Bioproducts Processing. 107: 104112. DOI: 10.1016/j.fbp.2017.10.008

[19] Li, T., P. Shen, W. Liu, C. Liu, R. Liang, N. Yan, and J. Chen. 2014. Major Polyphenolics in Pineapple Peels and Their Antioxidant Interactions. International Journal of Food Properties. 17(8): 1805-1817. DOI: 10.1080/10942912.2012.732168.

[20] da Silva, D. I., G. D. Nogueira, A. G. Duzzioni, and M. A. Barrozo. 2013. Changes of Antioxidant Constituents in Pineapple (Ananas comosus) Residue during Drying Process. Industrial Crops and Products. 50: 557-562.

[21] Živković, J., K. Šavikin, T. Janković, N. Ćujić, and N. Menković. 2018. Optimization of Ultrasound-assisted Extraction of Polyphenolic Compounds from Pomegranate Peel Using Response Surface
Methodology. Separation and Purification Technology. 194: 40-47. DOI: 10.1016/j.seppur.2017.11.032.

[22] Xu, D. P., J. Zheng, Y. Zhou, Y. Li, S. Li, and H. B. Li. 2017. Ultrasound-assisted Extraction of Natural Antioxidants from the Flower of Limonium Sinuatum: Optimization and Comparison with Conventional Methods. Food Chemistry. 217: 552-559. DOI: 10.1016/j.foodchem.2016.09.013.

[23] Sang, J., J. Sang, Q. Ma, X.-f. Hou, and C.-q. Li. 2017. Extraction Optimization and Identification of Anthocyanins from Nitraria Tangutorun Bobr. Seed Meal and Establishment of a Green Analytical Method of Anthocyanins. Food Chemistry. 218: 386-395. DOI: https://doi.org/10.1016/j.foodchem.2016.09.093.

[24] Wang, W., J. Jung, E. Tomasino, and Y. Zhao. 2016. Optimization of Solvent and Ultrasound-assisted Extraction for Different Anthocyanin Rich Fruit and Their Effects on Anthocyanin Compositions. LWT - Food Science and Technology. 72: 229-238. DOI: https://doi.org/10.1016/j.lwt.2016.04.041.

[25] Pyrzynska, K. and A. Pękal. 2013. Application of Free Radical Diphenylpicrylhydrazyl (DPPH) to Estimate the Antioxidant Capacity of Food Samples. Analytical Methods. 5(17): 4288-4295. DOI: 10.1039/C3AY40367J.

[26] Pękal, A. and K. Pyrzynska. 2014. Evaluation of Aluminium Complexation Reaction for Flavonoid Content Assay. Food Analytical Methods. 7(9): 1776-1782. DOI: 10.1007/s12161-014-9814-x.

[27] Morais, D. R., E.M. Rotta, S. C. Sargi, E. M. Schmidt, E. G. Bonafe, M. N. Eberlin, A. C. H. F. Sawaya, and J. V. Visentainer. 2015. Antioxidant Activity, Phenolics and UPLC-ESI(-)-MS of Extracts from Different Tropical Fruits Parts and Processed Peels. Food Research International. 77: 392-399. DOI: 10.1016/j.foodres.2015.08.036.

[28] da Silva, D. I. S., G. D. R. Nogueira, A. G. Duzzioni, and M. A. S. Barrozo. 2013. Changes of Antioxidant Constituents in Pineapple (Ananas comosus) Residue during Drying Process. Industrial Crops and Products. 50: 557-562. DOI: 10.1016/j.indcrop.2013.08.001

[29] Putri, D. A., A. Ulfi, A. S. Purnomo, and S. Fatmawati. 2018. Antioxidant and Antibacterial Activities of Ananas Comosus Peel Extracts. Mal. J. Fund. Appl. Sci. 14(2): 307311.

[30] Alothman, M., R. Bhat, and A. A. Karim. 2009. Antioxidant Capacity and Phenolic Content of Selected Tropical Fruits from Malaysia, Extracted with Different Solvents. Food Chemistry. 115(3): 785-788. DOI: 10.1016/j.foodchem.2008.12.005.

[31] Jovanović, M., M. Milutinović, M. Kostić, B. Miladinović, N. Kitić, S. Branković, and D. Kitić. 2018. Antioxidant Capacity of Pineapple (Ananas comosus (L.) Merr.) Extracts and Juice. Lekovite Sirovine. (38): 27-30. DOI: 10.5937/leksir1838027J.

[32] Miguel, M. G., S. Nunes, S. A. Dandlen, A. M. Cavaco, and M. D. Antunes. 2010. Phenols and Antioxidant Activity of Hydro-alcoholic Extracts of Propolis from Algarve, South of Portugal. Food and Chemical Toxicology. 48(12): 3418-23. DOI: 10.1016/j.fct.2010.09.014.

[33] Nithiyanantham, S., P. Siddhuraju, and G. Francis. 2013. A Promising Approach to Enhance the Total Phenolic Content and Antioxidant Activity of Raw and Processed Jatropha Curcas L. Kernel Meal Extracts. Industrial Crops and Products. 43: 261-269. DOI: 10.1016/j.indcrop.2012.07.040.

[34] Kaneria, M. J. and S. V. Chanda. 2012. The Effect of Sequential Fractionation Technique on the Various Efficacies of Pomegranate (Punica granatum L.). Food Analytical Methods. 6(1): 164-175. DOI: 10.1007/s12161012-9412-8. 